\title{
ATYPICAL PRESENTATION OF LATE-ONSET SANDHOFF DISEASE: A CASE REPORT
}

\author{
András SALAMON', László SZPISJAK' ${ }^{1}$, Dénes ZÁDORI' ${ }^{1}$ István LÉNÁRT², Zoltán MARÓTI , Tibor \\ KALMÁR ${ }^{3}$, Charlotte M. H. BRIERLEY4 ${ }^{4}$ Patrick B. DEEGAN ${ }^{5}$, Péter KLIVÉNYI ${ }^{1}$
}

\author{
'Department of Neurology, University of Szeged, Szeged, Hungary \\ ${ }^{2}$ Department of Pediatrics and Pediatric Health Center, University of Szeged, Szeged, Hungary \\ ${ }^{3}$ Genetic Diagnostic Laboratory, Department of Pediatrics and Pediatric Health Center, \\ University of Szeged, Szeged, Hungary \\ ${ }^{4}$ Department of Neurology, Addenbrooke's Hospital, Cambridge, United Kingdom \\ ${ }^{5}$ Department of Medicine, University of Cambridge, Addenbrooke's Hospital, Cambridge, United Kingdom
}

\begin{abstract}
Introduction - Sandhoff disease is a rare type of hereditary (autosomal recessive) GM2-gangliosidosis, which is caused by mutation of the HEXB gene. Disruption of the $\beta$ subunit of the hexosaminidase (Hex) enzyme affects the function of both the Hex-A and Hex-B isoforms. The severity and the age of onset of the disease (infantile or classic; juvenile; adult) depends on the residual activity of the enzyme. The late-onset form is characterized by diverse symptomatology, comprising motor neuron disease, ataxia, tremor, dystonia, psychiatric symptoms and neuropathy.

Case report - A 36-year-old female patient has been presenting progressive, symmetrical lower limb weakness for 9 years. Detailed neurological examination revealed mild symmetrical weakness in the hip flexors without the involvement of other muscle groups. The patellar reflex was decreased on both sides. Laboratory tests showed no relevant alteration and routine electroencephalography and brain MRI were normal. Nerve conduction studies and electromyography revealed alterations corresponding to sensory neuropathy. Muscle biopsy demonstrated signs of mild neurogenic lesion. Her younger brother (32-year-old) was observed with similar symptoms. Detailed genetic study detected a known pathogenic missense mutation and a 15,088 base pair long known pathogenic deletion in the HEXB gene (NM 000521.4:c.1417G>A; NM 000521:c.-376$583 \overline{6} \_669+1473$ del; double heterozygous state). Segregation analysis and hexosaminidase enzyme assay of the family further confirmed the diagnosis of late-onset Sandhoff disease.
\end{abstract}

\author{
KÉSÖI KEZDETÚ SANDHOFF-BETEGSÉG ATÍPUSOS \\ JELENTKEZÉSE: ESETISMERTETÉS \\ Salamon A, MD; Szpisjak L, MD; Zádori D, MD; Lénárt I, \\ MSc; Maróti Z, MSc; Kalmár T, MSc; Brierley CMH, MD; \\ Deegan PB, MD; Klivényi P, MD, PhD, DSc \\ Ideggyogy Sz 2021;74(11-12):425-429.
}

Correspondent: Péter KLIVÉNYI, MD, PhD, DSc, Department of Neurology, University of Szeged; H-6725 Szeged, Semmelweis u. 6. Hungary. Telefon: +36 62 545-351, fax: + 3662 545-597.

E-mail: klivenyi.peter@med.u-szeged.hu

Érkezett: 2021. augusztus 5. Elfogadva: 2021. augusztus 27. 
Conclusion - The purpose of this case report is to draw attention to the significance of late-onset Sandhoff disease amongst disorders presenting with proximal predominant symmetric lower limb muscle weakness in adulthood.

Keywords: Sandhoff disease; hexosaminidase; motor neuron disease; muscle weakness
NM_000521:c.-376-5836_669+1473del; kettös heterozigóta állapot). A szegregációanalízis, valamint a családtagok hexózaminidáz-vizsgálata a késói kezdetü Sandhoffbetegség diagnózisát megerősítették.

Konklúzió - A jelen esetismertetés célja, hogy felhívja a figyelmet a késői kezdetű Sandhoff-betegség differenciáldiagnosztikai jelentőségére felnőttkorban kezdődő, proximális predominanciát mutató szimmetrikus alsó végtagi gyengeség esetén.

Kulcsszavak: Sandhoff-betegség, hexózaminidáz, motoneuron-betegség, izomgyengeség

The purpose of this report is to present a case of a patient with a genetically confirmed, atypical presentation of late-onset Sandhoff disease. Furthermore, we draw attention to the differential diagnostic significance of late-onset Sandhoff disease underlying proximal predominant symmetric lower limb muscle weakness in adulthood.

\section{Case report}

A 36-year-old female patient was referred to our outpatient clinic for 9 years of progressive, symmetrical lower limb weakness as well as falls. Occasionally, she also had muscle cramps and muscle pain in her legs, and often felt like she was losing strength from her legs when climbing stairs or standing up. The symptoms showed no daily fluctuation. Her limbs were a little thinner, however she did not notice any pronounced atrophy or fasciculations. Detailed neurological examination revealed mild symmetrical weakness (MRC/Medical Research Council muscle strength grading scale: $4 / 5$ ) in the hip flexors, without the involvement of other muscle groups. The patellar reflex was decreased on both sides. She had a mild thoracolumbar scoliosis ("S"-shaped). Further detailed physical examinations of the patient showed no other abnormalities (e.g. ataxia, organomegaly, urinary incontinence). The performed laboratory tests were no relevant. Routine electroencephalography and brain MRI were normal. Lumbar spine MRI showed minimal multilevel degenerative changes without significant central canal stenosis or neural foraminal narrowing. Nerve conduction studies and electromyography revealed alterations corresponding to sensory neuropathy and right-sided L5 radiculopathy. The muscle biopsy demonstrated signs of mild neurogenic lesion. Of note, the 
mother of the proband (62-year-old), who is treated at our clinic with late-onset chorea and neurocognitive impairment, has no similar muscle weakness. The proband has two siblings. Her younger brother (32-year-old) is treated at the University of Cambridge with similar symptoms (he first noticed symptoms at the age of 16 years, mainly weakness of knee extension; power is reduced in knee extension and hip flexion (4/5 MRC scale); the muscle biopsy of the vastus lateralis showed non-diagnostic end-stage muscle atrophy). The elder sister of the proband is asymptomatic (39-year-old) (Figure 1. A).

Following that possible secondary etiologies were excluded, a detailed genetic study was performed. The possibility of Huntington's disease has arisen in the background of symptoms of the mother of the proband, therefore, the IT15 gene was examined (genomic DNA PCR amplification followed by electrophoresis), which revealed one normal (20 CAG repeats) and one expanded (37 CAG repeat with decreased penetrance) allele, which may explain her symptoms. We did not find this expansion in the other members of the family (Figure 1. A). A reanalysis of the whole exome sequencing data was performed in the brother of the proband. We detected a known pathogenic missense variant in heterozygous form in the HEXB gene (exon 11$)^{5}$. This mutation was also identified in our proband (NM_000521.4:c.1417G >A / NP_000512.2:p.Gly473Ser; rs762892362). Following the detection of the mutation, detailed family serum hexosaminidase enzyme testing was performed, the results of which supported the possibi-

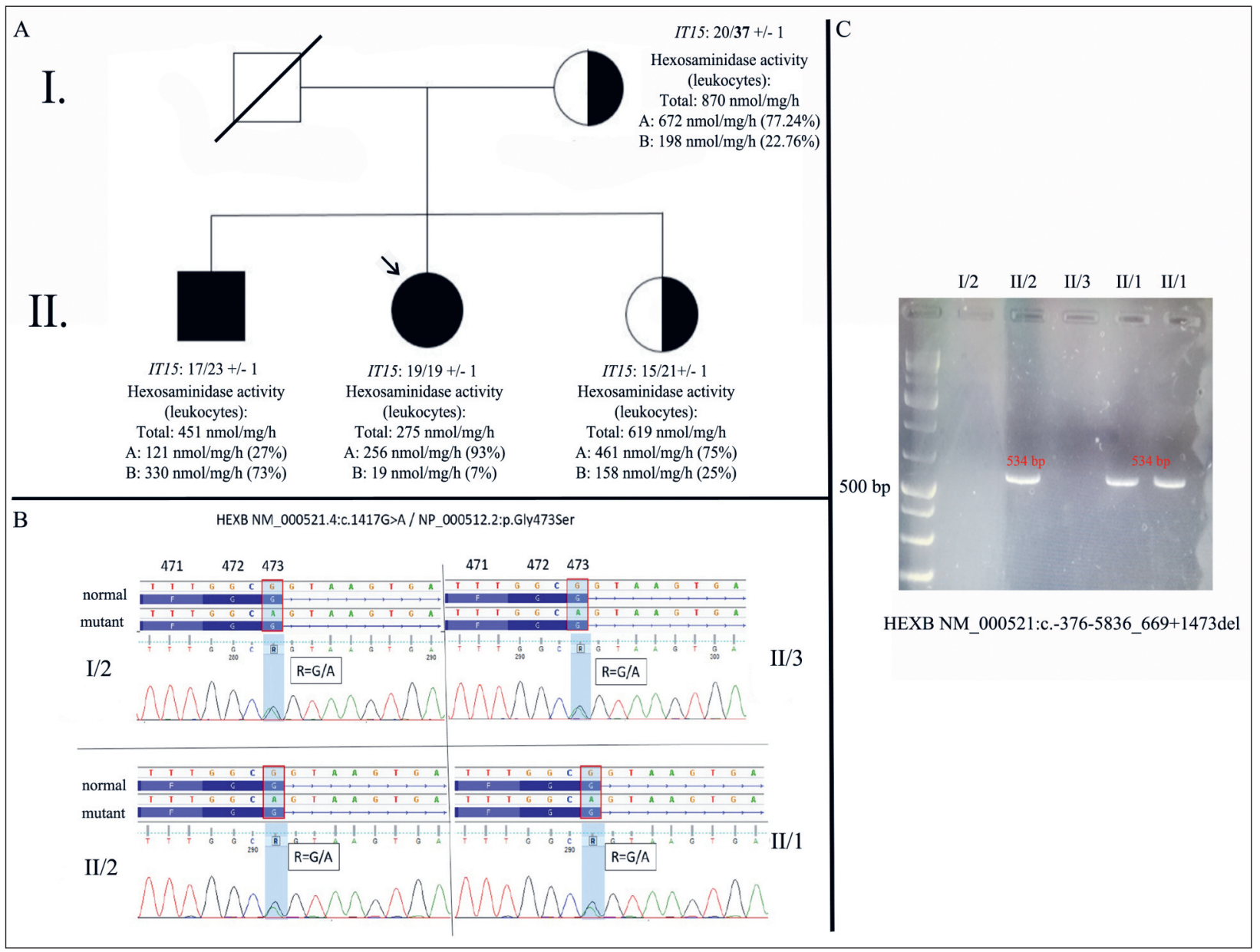

Figure 1. Pedigree (A), chromatograms (B) and detection of the deletion (C) (NM_000521:c.-3765836_669+1473del) in the family. The generations are signed with Roman numbers. The deceased member is crossed. Individuals with symptoms are marked in black. The proband is indicated by an arrow. The carrier state is indicated by a half-filled circle / rectangle. The results of the IT15 gene (genomic DNA PCR amplification followed by electrophoresis) and the hexosaminidase enzyme assays (leukocytes) were indicated as well

bp: base pair, IT15: interesting transcript 15 gene; p: proband 
lity of late-onset Sandhoff disease (Figure 1. B). Therefore, deletion and duplication analyses was carried out, which detected a 15,088 base pair long known pathogenic deletion in the HEXB gene (NM_000521:c.-376-5836_669+1473del) ${ }^{7},{ }^{13-15}$. Segregation analysis of the family further strengthened the diagnosis of late-onset Sandhoff disease caused by the co-presence of two known pathogenic mutations (double trans heterozygous state) (Figure 1. C). Although no proven effective treatment is known for our proband, both the patient and her affected younger brother reported a beneficial effect of a gluten- and cow's milk protein free diet (minimal improvement in muscle mass and muscle strength).

Written informed consent was obtained from all individual participants for whom identifying information is included in this article (Regional Human Biomedical Research Ethics Committee of the University of Szeged; registration number: 44/2016.). All procedures performed in studies involving human participants were in accordance with the ethical standards of the Regional Human Biomedical Research Ethics Committee of the University of Szeged and with the 1964 Helsinki declaration and its later amendments or comparable ethical standards.

\section{Discussion}

The purpose of the above case report is to draw attention to the differential diagnostic significance of possible late-onset Sandhoff disease underlying proximal predominant symmetric lower limb muscle weakness in adulthood. To the best of our knowledge, the co-occurrence (double trans heterozygous) of the two known pathogenic mutations detected in the proband and her brother has not been reported to date. Sung et al. (2018) reported a case with a similar clinical picture (40-year-old woman with three years history of slowly progressive weakness in the lower extremities) in which one of the mutations (c.1417G $>A$; G473S) we detected was associated with the c.298delC pathogenic variant (compound heterozygous mutation) ${ }^{5}$. In their paper, the significance of the G473S missense mutation was confirmed by high inter-species conservation and low hexosaminidase activity in leukocytes. The occurrence of the 15,088 base pair long deletion detected by the current analysis (NM_000521:c.-376-5836_669+1473del) has been described in several previous publications ${ }^{7,13-15}$. The mutation was identified by Bikker et al. (1989) in two, not related children with classical Sandhoff disease phenotype and enzymatic results (although mutational screening for the other allele has not been performed in details) ${ }^{14}$. Chardon et al. (2015) detected the same deletion in addition to a missense mutation (NM_000521.3:c.1250C>T; p.Pro417Leu) in a patient with very late-onset Sandhoff disease phenotype presenting as Kennedy disease (the results of the enzymatic assays were also consistent $)^{7}$. Lee et al. (2000) found in addition to the deletion a missense mutation as well $(\mathrm{T} 437 \mathrm{P})^{15}$. The disease in this case was of childhood onset, and the enzyme test results also showed significant decrease in hexosaminidase function (Total: $67.8 \mathrm{nmol} / \mathrm{mg} / \mathrm{h}$; HexA: $5.8 \%$; HexB: 0.56\%). Overall, the co-occurrence of the 2 detected variants resulted in late-onset Sandhoff disease with slow progression and moderately decreased hexosaminidase activity.

\section{ACKNOWLEDGEMENTS}

We acknowledge Mr. Evan Reid, MD for his contribution of the manuscript.

\section{REFERENCES}

1. Scarpelli M, Tomelleri G, Bertolasi L, Salviati A. Natural history of motor neuron disease in adult onset GM2-gangliosidosis: a case report with 25 years of follow-up. Mol Genet Metab Rep 2014;1:269-72. https://doi.org/10.1016/j.ymgmr.2014.06.002

2. Gomez-Lira M, Sangalli A, Mottes M, Perusi C, Pignatti $P F$, Rizzuto $N$, et al. A common beta hexosaminidase gene mutation in adult Sandhoff disease patients. Hum Genet 1995;96:417-22.

https://doi.org/10.1007/BF00191799

3. Clarke JT, Mahuran DJ, Sathe S, Kolodny EH, Rigat BA,
Raiman JA, et al. An open-label phase I/II clinical trial of pyrimethamine for the treatment of patients affected with chronic GM2 gangliosidosis (Tay-Sachs or Sandhoff variants). Mol Genet Metab 2011;102:6-12. https://doi.org/10.1016/j.ymgme.2010.09.004

4. Delnooz CC, Lefeber DJ, Langemeijer SM, Hoffjan S, Dekomien $G$, Zwarts MJ, et al. New cases of adult-onset Sandhoff disease with a cerebellar or lower motor neuron phenotype. J Neurol Neurosurg Psychiatry 2010; 81:968-72.

https://doi.org/10.1136/jnnp.2009.177089 
5. Sung AR, Moretti $P$, Shaibani A. Case of late-onset Sandhoff disease due to a novel mutation in the HEXB gene. Neurol Genet 2018;4:e260. https://doi.org/10.1212/NXG.0000000000000260

6. Khoueiry M, Malek E, Salameh JS. Adult onset Sandhoff disease: a rare mimicker of amyotrophic lateral sclerosis. Amyotroph Lateral Scler Frontotemporal Degener 2020; 21:144-6. https://doi.org/10.1080/21678421.2019.1663214

7. Chardon JW, Bourque PR, Geraghty MT, Boycott KM. Very late-onset Sandhoff disease presenting as Kennedy disease. Muscle Nerve 2015;52:1135-6. https://doi.org/10.1002/mus.24775

8. Chester MA, Hultberg B, Liedholm H, Ockerman PA. A new $\mathrm{N}$-acetyl-beta-D-hexosaminidase disease with late onset of progressive neurological symptoms. Hum Hered 1979;29:124-8 https://doi.org/10.1159/000153028

9. Rattay TW, Schöls L, Wilhelm C, Synofzik M. Late adultonset pure spinal muscular atrophy due to a compound HEXB macro-deletion. Amyotroph Lateral Scler Frontotemporal Degener 2013;14:628-9. https://doi.org/10.3109/21678421.2013.812662

10. Streifler JY, Gornish M, Hadar H, Gadoth N. Brain imaging in late-onset GM2 gangliosidosis. Neurology 1993; 43:2055-8.

https://doi.org/10.1212/wnl.43.10.2055
11. Maegawa GH, Tropak M, Buttner J, Stockley T, Kok F, Clarke JT, et al. Pyrimethamine as a potential pharmacological chaperone for late-onset forms of GM2 gangliosidosis. J Biol Chem 2007;282:9150-61. https://doi.org/10.1074/jbc.M609304200

12. Masciullo M, Santoro M, Modoni A, Ricci E, Guitton J, Tonali $P$, et al. Substrate reduction therapy with miglustat in chronic GM2 gangliosidosis type Sandhoff: results of a 3-year follow-up. J Inherit Metab Dis 2010;33:S355-61. https://doi.org/10.1007/s10545-010-9186-3

13. Ankala A, Kohn JN, Hegde A, Meka A, Ephrem CL, Askree $S H$, et al. Aberrant firing of replication origins potentially explains intragenic nonrecurrent rearrangements within genes, including the human DMD gene. Genome Res 2012; 22:25-34. https://doi.org/10.1101/gr.123463.111

14. Bikker H, van den Berg FM, Wolterman RA, de Vijlder JJ, Bolhuis PA. Demonstration of a Sandhoff disease-associated autosomal 50-kb deletion by field inversion gel electrophoresis. Hum Genet 1989;81:287-8. https://doi.org/10.1007/BF00279006

15. Lee EH, Park JH, Coe CJ, Hahn SH. A novel mutation in the beta-hexosaminidase beta-subunit gene in a 14-monthold Korean boy with Sandhoff disease: first reported Korean case. Hum Mutat 2000;16:180-1. https://doi.org/10.1002/1098-1004(200008)16:2<180: AID-HUMU21>3.0.CO;2-X 